\title{
Алтайцы, тувинцы, хакасы: вовлечение в урбанизационные процессы
}

Миграция сельского населения в города является общемировой тенденцией, и коренные народы Южной Сибири в этом смысле не исключение. Конечно, процесс адаптации народов, традиционно проживающих в сельской местности, проходит непросто из-за разности городского и сельского образа жизни. Ещё Г. Зиммель отмечал глубокий контраст между жизнью большого города и деревни, отличающейся медленным, привычным и равномерным ритмом душевной и умственной жизни [12, с. 2]. Сельское сообщество отличается небольшими размерами, относительно однородным составом, высоким уровнем коллективной сплочённости [33, p. 297], в городе, несмотря на тесно соприкасающиеся друг с другом дома, отсутствует специфическое для общества соседей личное знакомство [6, с. 9]. Город часто рассматривается с позиции публичных отношений, соответствующих избирательной воле (Gesellschaft), a село - сквозь призму близких и доверительных отношений, которые соответствуют сущностной воле (Gemeinschaft) [25, с. 9-10]. Конечно, в нынешних условиях границы между городским и сельским не столь контрастны, но все же сказываются на адаптивных возможностях сельчан.

В широком смысле адаптация рассматривается и как процесс, и как результат взаимодействия индивида (группы) с кардинально изменяющейся социальной средой $[\mathbf{2 8}$, с. 82]. Безусловно, вовлечение сельского населения в урбанизационные процессы приводит к трансформации не только социального пространства города, но и фризического. Ещё представители Чикагской школы в своих исследованиях наглядно показали, как меняется структура города под влиянием социальных фракторов [32, p. 51]. Возможно несколько "сценариев" развития: создание особой среды, сочетающей и городские, и сельские характеристики [16, с. 6], формирование диаспоральных сообществ внутри городской среды [10, c. 264], стратегия изоляционного проживания сельских мигрантов [8, с. 34] и др. По мнению исследователей, российская сельская местность имеет своё продолжение в городах, подавляющая часть жителей которых - горожане в первом или втором поколении, для которых сельские ценности по-прежнему играют очень большую роль $[\mathbf{1 ,}$ с. 66]. Можно сказать, что некоторые элементы сельской жизни "мигрируют" вместе с их носителями, меняя городское пространство.

Стратегия адаптивного поведения сельских мигрантов может выстраиваться по-разному. Например, К.И. Казенин полагает, что в процессе адаптации мигрант может ориентироваться на разные социальные институты: на широкий круг родственников, на друзей, приятелей, знакомых или на самого себя и собственную семью [16, с. 13]. Еще У. Томас и Ф. Знанецкий подчеркивали роль первичной группы в процессе адаптации мигранта, которая, с одной стороны, формирует у него чувство ответственности, а с другой - создает ему ощущение безопасности $[37$, p. 344]. По данным зарубежных исследований, $74 \%$ сельских мигрантов находят работу именно через личные связи (родственников, друзей, земляков-односельчан) [36, p. 11]. В процессе адаптации мигранты могут ориентироваться на стратегию "максимизации доходов", предполагающую поиск дополнительных источников заработка или на стратегию "минимизации расходов", связанную с сокращением расходов [29, p. 27]. Конечно, экономические критерии успешности адаптации важны, однако их нельзя считать достаточным основанием для оценки адаптированно-

\section{(C) Лушникова О. Л., 2021}

ЛУШНИкОВА Ольга Леонидовна, канд. социол. наук, старший научный сотрудник сектора экономики и социологии Хакасского научно-исследовательский института языка, литературы и истории (2. Абакан). E-mail: oltolt@mail.ru 
сти. Например, некоторые исследователи считают, что даже те, кто обладает достаточными фринансовыми ресурсами, могут по-прежнему чувствовать себя сельскими жителями [30, p. 559]. И наоборот, иногда менее адаптированные мигранты всячески стараются репрезентировать себя как местных, по возможности скрывая или хотя бы не афишируя своё сельское происхождение $[8$, c. 44$]$

Одни исследования доказывают, что более высокий профессионально-образовательный уровень благоприятствует более успешной адаптации [34, p. 10], согласно другим - "знание и опыт" занимает последнее место в иерархии фокторов, определяющих успех адаптации [9, с. 29]. Вполне вероятно, что на первоначальном этапе своего пребывания мигранты "соглашаются" на любую работу, в том числе не соответствующую их профессионально-квалификационному уровню. Однако В.И Мукомель считает, что по мере адаптации части мигрантов удаётся вернуться на рабочие места, соответствующие их уровню квалификации и профессиональной подготовки [19, с. 77]. Вообще исследователи полагают, что в процессе адаптации значение имеет собственная целеустремлённость и активность, среди них - адаптированных более чем в 2 раза больше, чем среди уповающих главным образом на положение дел в обществе [22, с. 91].

Цель статьи связана с анализом адаптационных процессов алтайцев, тувинцев и хакасов при переселении из сельской местности в городскую. Основной теоретической посылкой является исследование адаптации с точки зрения подхода, представленного в работах У. Томаса и Ф. Знанецкого. В соответствии с ним процесс адаптации предполагает организацию и устройство личной жизни индивида (в т.ч. работы, быта, отдыха), усвоение норм и требований общества, взаимодействие с ближайшим окружением [36, p. 937]. Поэтому основной фокус исследования направлен на изучение практик городской жизни, на формирование городской идентичности (или сохранение исходной - сельской), взаимодействие приезжих из села с акторами городской среды, включенность в социально-культурную жизнь города. Не менее важным является изучение трансформации этнической идентичности в качестве оценки влияния урбанизации на сохранение коренных народов (благоприятствующего или усугубляющего).

\section{Алтайцы, тувинцы, хакасы: коренные народы Южной Сибири}

К коренным народам Южной Сибири относят алтайцев, тувинцев и хакасов. Традиционно эти этносы проживают в сельской местности, однако с индустриальным развитием представители коренных народов стали активно включаться в урбанизационные процессы, причём у каждого из этносов процесс освоения города происходил по-своему.

Алтайць - небольшой этнос, по данным последней переписи населения, их насчитывалось 68,8 тыс. чел. (проживающих на территории республики Алтай) (табл. 1). Однако от общей численности населения они составляют треть, поскольку всего в регионе проживает 206,2 тыс. чел. В республике всего одно городское поселение - столица региона г. Горно-Алтайск, где проживает меньше 27,6\% всего населения республики. Большая часть алтайцев проживает в сельских поселениях, причём наиболее компактно они проживают на территории трёх районов, в остальных районах проживают преимущественно русские. Больше русских и в столице республики, алтайцы в общей структуре городского населения составляют всего $22,3 \%$.

Конечно сельская местность - более привычная среда для алтайцев, поскольку традиционные виды деятельности связаны с проживанием в селе: животноводство, охота, собирательство $[11$, с. 436]. Однако соџиально-экономические процессы вынуждают алтайцев приспосабливаться жить и в городских условиях. По данным С.П. Тюхтеневой, процесс массовой миграции алтайцев в город начался ещё в 1990-е гг. в связи с ликвидацией малокомплектных школ, причём распространенной была ситуация переезда только матери с детьми школьного возраста, а отец оставался в селе, чтобы сохранить хозяйство [26, с. 77]. Сегодня обучение детей по-прежнему остается основной целью переселения [23, с. 92], однако в нынешних условиях актуальны и другие причины переезда. Исследователи отмечают сложное социально-экономическое положение алтайцев, связанное с проживанием в местностях с 
Таблица 1. Структура населения республик Алтай, Тыва, Хакасия

\begin{tabular}{|l|r|r|c|}
\hline & Алтай & Тыва & Хакасия \\
\hline Численность населения республики, тыс. чел. & 206,2 & 307,9 & 534,3 \\
\hline Удельный вес городского населения, \% & 27,6 & 53,1 & 67,3 \\
\hline Численность коренного этноса, тыс. чел. & 68,8 & 249,3 & 63,6 \\
\hline $\begin{array}{l}\text { Удельный вес коренного этноса, } \\
\text { проживающего в городских поселениях, \% }\end{array}$ & 18,4 & 46,8 & 38,3 \\
\hline Удельный вес коренного этноса среди городского населения, \% & 22,3 & 71,4 & 6,8 \\
\hline
\end{tabular}

Источник: составлено по: [13, с. $11 ; 14$, с. $566,573,575]$.

суровым климатом и экстремальными условиями, а также с высоким уровнем безработицы, распространением пьянства, алкоголизма и других заболеваний $[11$, c. 436]. С одной стороны, у алтайцев сильны традиции многодетности (на 1000 алтайских женщин в среднем приходится 2080 рождённых детей [15, c. 1221]), поэтому их численность пока сохраняется, но с другой стороны, проживание в городской, преимущественно русскоговорящей среде, и межнациональные браки размывают этническую идентичность современных алтайцев.

Тувиниы - один из многочисленных этносов Сибири, в республике Тыва их насчитывается 249,3 тыс. чел. (табл. 1). Численность тувинцев увеличивается благодаря высокому естественному приросту населения: среднее число рождённых детей на 1000 тувинских женщин составляет 2028 [15, с. 1231]. Кроме того, в регионе они составляют абсолютное большинство $(80,9 \%)$. Интенсивная внутриреспубликанская миграция тувинцев (преимущественно из села в город) привела к увеличению среди них городских жителей, в структуре городского населения они составляют $71,3 \%$.

Согласно данным исследований, освоение городского образа жизни для тувинцев было сложным. Включение в городскую среду осложнялось отсутствием опыта к индустриальному труду, прочными связями с ведением кочевого образа жизни и неграмотностью населения [18, с. 69]. В настоящее время причины отъезда сельских жителей преимущественно сводятся к улучшению условий жизни: чаще всего к выезду побуждает отсутствие работы $(63,8 \%)$, учеба $(40,5 \%)$, экономические проблемы $(26,6 \%)$, коррупщия $(23,4 \%)$, преступность, распространённость пьянства и наркомании $(23 \%)$ [17, с. 59]. Вместе с тем исследователи отмечают наличие у тувинцев некоторых черт национального характера, которые снижают их адаптационные возможности: например, непунктуальность, фрлегматизм, сильная зависимость от родственных отношений [24, с. 160], иждивенческая психология, отсутствие трудового воспитания в семье и школе [2, с. 116].

Хакасы составляют $12,0 \%$ от общей численности населения республики, всего их насчитывается 63,6 тыс. чел., при этом большая часть хакасов - преимущественно сельское население (61,6\%) (табл. 1). Наиболее компактно хакасы проживают на территории двух районов. По сравнению с другими республиками Хакасия считается наиболее урбанизированной: в городах проживает $69,8 \%$ всего населения, однако хакасы в общей структуре горожан составляют всего $6,8 \%$.

Хакасы по сравнению с другими этносами, проживающими на территории региона, отличаются более низкой миграционной активностью [27, c. 58], преимущественно мигрируют в направлении "село - крупное село" [4, c. 150], а также более склонны к "возвратной" миграции - обратно в село [20, c. 16]. Данные этносоциологических исследований 2000-х гг. доказывают, что хакасы испытывали трудности адаптации. Согласно результатам, русские в тот период сосредоточивались преимущественно в отраслях тяжёлой промышленности с хорошими заработками и богатой социальной базой, а хакасы в основном работали на мелких предприятиях лёгкой и пищевой промышленности с невысокой заработной платой, и в целом считали, что у них меньше 
Рис. 1. Соотношение идентичностей среди алтайцев, тувинцев и хакасов, в \% от опрошенных

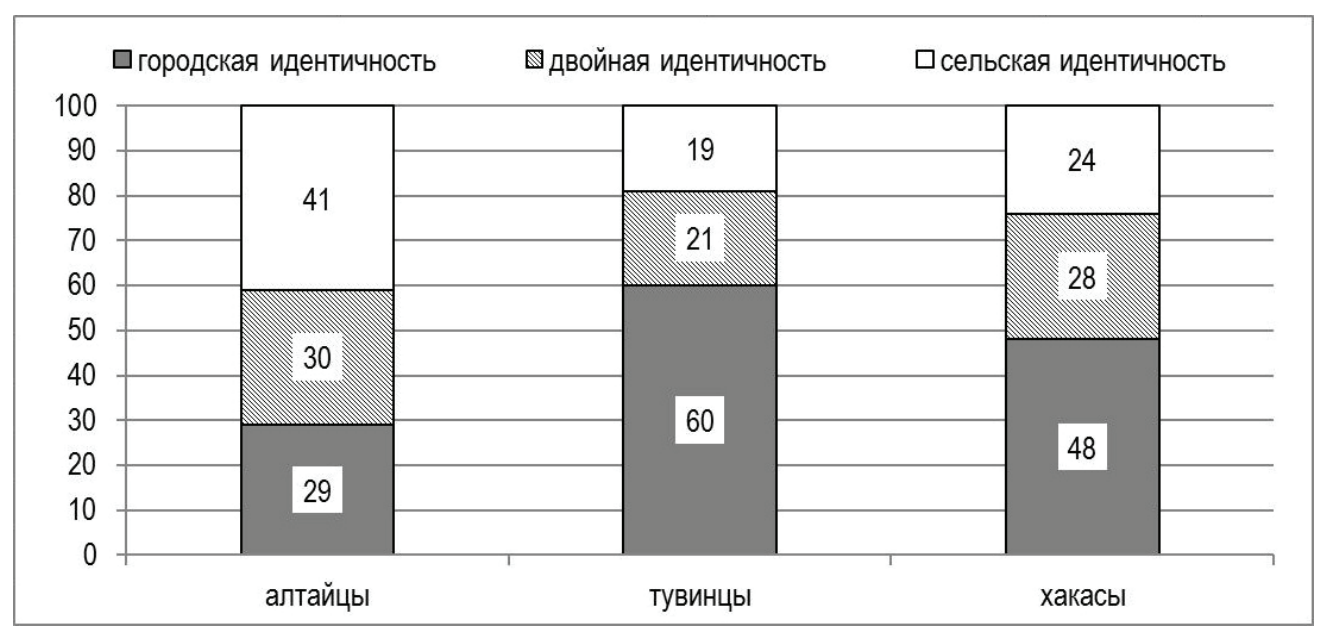

Источник: составлено автором

возможностей карьерного роста [21, с. 3]. Поэтому, с одной стороны, высокий уровень урбанизации благоприятствует миграции хакасов в городскую местность, но с другой стороны, процесс адаптации для них иногда оказывается сложным.

\section{Эмпирическая база}

Эмпирическую базу исследования составили материалы социологического опроса, который проводился в городских поселениях республик Алтай, Тыва и Хакасия в августе-сентябре 2019 г.

Генеральная совокупность - бывшие сельские жители титульных этносов Южной Сибири (алтайцы, тувинцы, хакасы), проживающие в городах и поселках городского типа каждой из титульных республик. При фрормировании выборочной совокупности использовались данные о половозрастной структуре городского населения каждой из республик, поскольку значительная часть городского населения в этих регионах - некоренные горожане (проживают не с рождения). Квоты (по полу и возрасту) также были введены во избежание формирования однородной выборочной совокупности. Опрос проводился методом формализованного интервью.

Опрос проводился в микрорайонах наиболее компактного проживания представителей титульных этносов. Также отбор респондентов осуществлялся в предполагаемых местах наибольшей концентрации приезжих из села: в общежитиях, в гостинках и т.д. Проводился уличный опрос, также для поиска респондентов использовался метод "снежного кома". Всего было опрошено 1184 чел.: в республике Алтай 327 чел., в Туве - 357 чел., в Хакасии - 500 чел. В результате выбраковки некачественно заполненных опросных листов и ремонта выборки анализировались данные 960 анкет. Обработка данных производилась с использованием прикладного пакета статистической обработки данных IBM SPSS Statistics 19.

\section{Освоение городского образа жизни}

Освоение городского образа жизни у алтайцев, тувинцев и хакасов происходит по-разному, что связано с особенностями исторического, политического, этнокультурного развития этих этносов.

У алтайцев, например, более выражены образовательные причины миграции в городскую местность, что подтверждается другими исследованиями [26, с. 77; 23, с. 92]. То есть основной причиной переезда для современных алтайцев является желание либо самим повысить свой образовательный 
Рис. 2. Жилищные условия алтайцев, тувинцев и хакасов, в \% от опрошенных

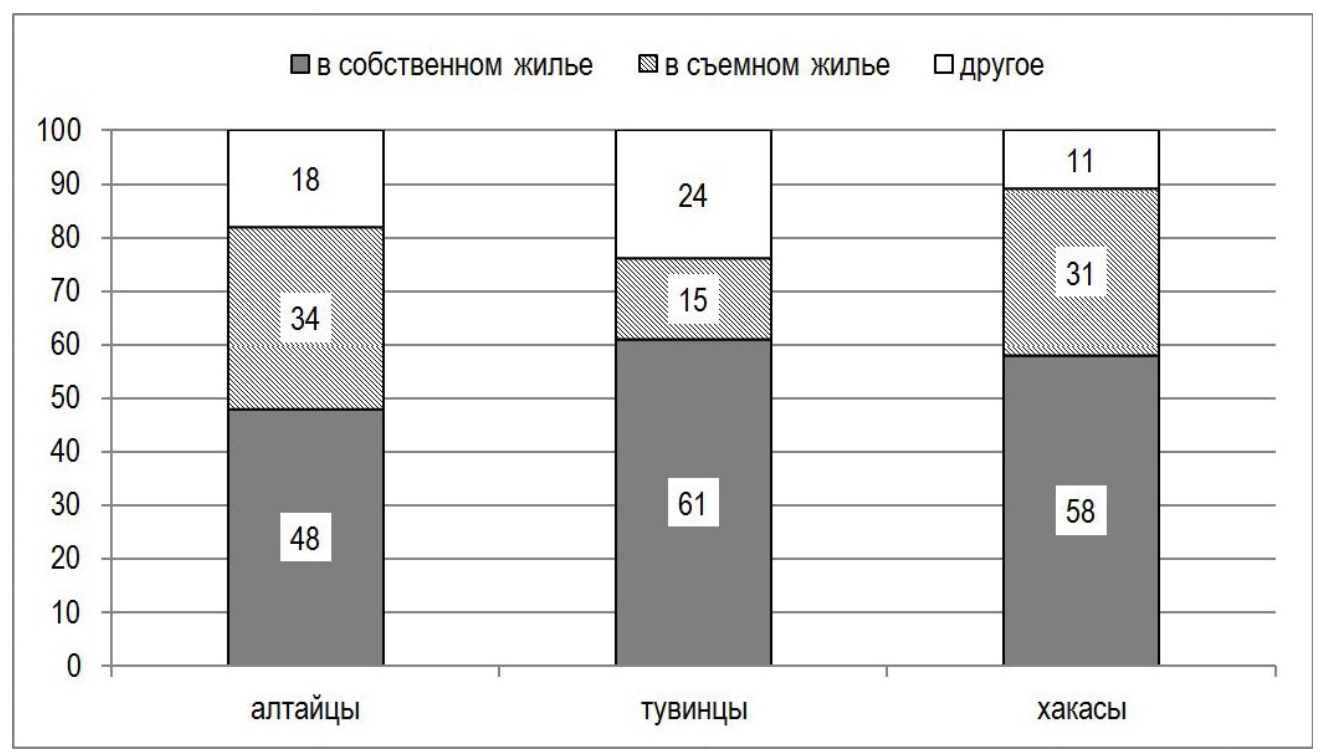

Источник: составлено автором

уровень, либо обеспечить условия для получения образования своим детям. Вероятно, поэтому больше половины (59 \%) приезжих алтайцев допускают для себя возможность вернуться обратно в родное село. Стратегия "временной" миграции (например, для получения образования) является довольно распространённой [32, p. 142].

Большая часть алтайцев сохраняет тесные связи с родной деревней: три четверти (74\%) опрошенных ответили, что часто ездят в ту деревню, откуда приехали. Возможно, поэтому алтайцам сложно дается принятие новой роли - в качестве горожанина: только 29 \% из них ассоциируют себя с городскими жителями - могут уверенно назвать себя горожанами, либо только становятся ими (puc. 1). Почти треть (30 \%) опрошенных алтайцев ощущают себя двояко: и в качестве городского жителя, и в качестве сельского. Ещё 41 \% ответили, что, несмотря на проживание в городе, в душе они всегда останутся сельскими жителями, либо вообще никогда не станут горожанами.

Возможно, сложности принятия новой роли связаны с трудностями взаимодействия с акторами городской среды. Две трети (62\%) опрошенных в исследовании алтайцев ответили, что не поддерживают дружеских отношений со своими соседями: треть из них (39 \%) ограничивается фрормальным общением ("только здороваемся") и ещё четверть (23 \%) не знакомы со своими соседями или вообще отмечают с их стороны неприязненное к себе отношение. Можно предположить, что сложности взаимодействия алтайцев с горожанами связаны с численным дисбалансом титульного этноса и этнического большинства (русскими). Некоторые исследователи отмечают сложный характер взаимоотношений алтайцев и русских, которые исторически сложились на территории республики. Например, Н.А. Тадина отмечает сформировавшийся ещё в советское время стереотип русского этноса как "носителя социального прогресса" наряду с прочно укоренившимся стереотипом об "этнической второсортности" алтайцев, связанном с убежденностью в невысоких деловых качествах и низком культурном уровне алтайцев, как и других сибирских народов [23, c. 91]. Возможно, поэтому большинство приезжих особо остро ощущает в городе нехватку поддержки родных и близких (44 \%), которые, по всей видимости, прежде всего ассоциируются с представителями своей национальности.

Безусловно, главной "экономической" проблемой для переехавших из села алтайцев является "жилищный вопрос" (45 \%), треть (34 \%) опрошенных проживает в съёмном жилье (рuс. 2). Кроме того, именно отсутствие собствен- 
Рис. 3. Направления предполагаемой миграции алтайцев, тувинцев и хакасов, в \% от опрошенных

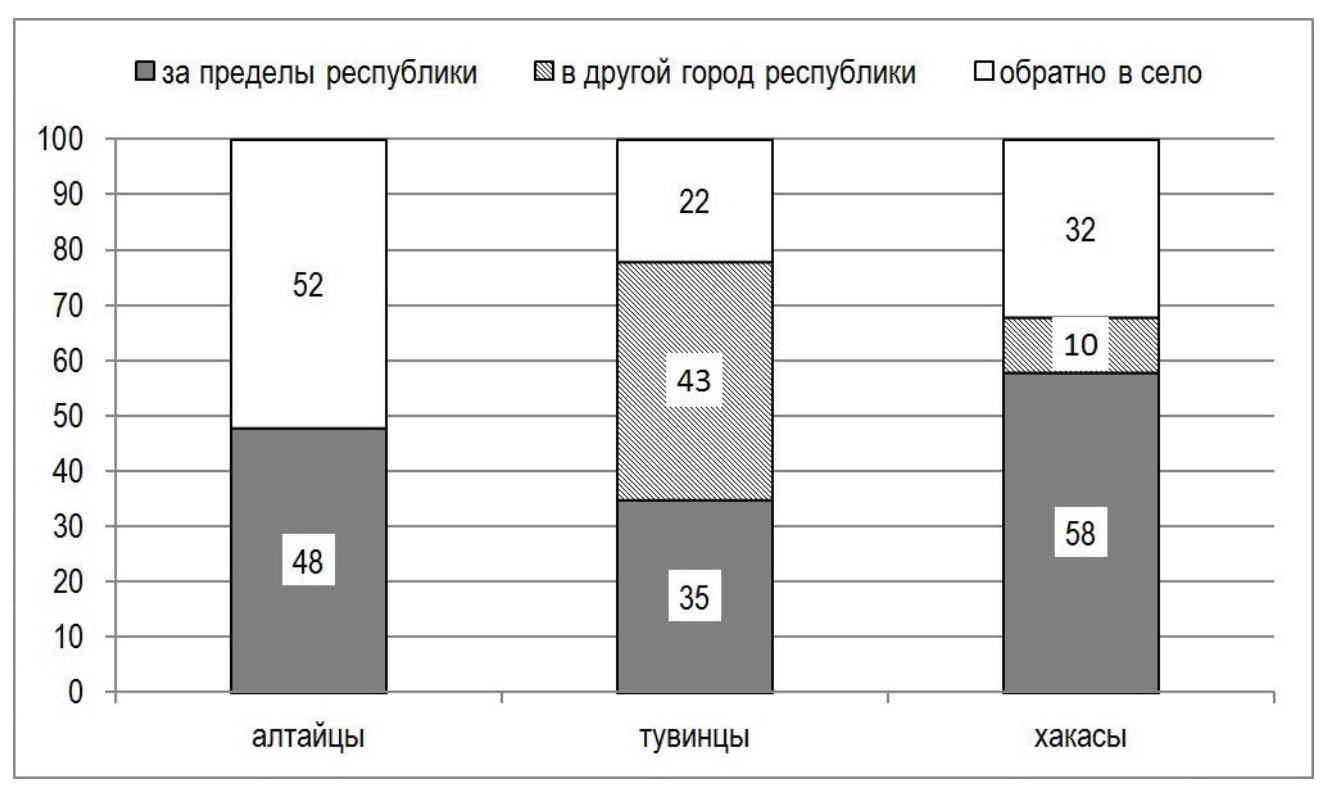

Источник: составлено автором

ного жилья для большинства алтайцев (44 \%) является главной потенциальной причиной возвращения в родное село.

Вообще село в представлении алтайцев ассоциируется с домом, родными людьми, безопасностью. Дом является средоточием и телом родства, поскольку общность крови [Blut] развивается и обособляется в общность места [Ort], а последняя - в общность духа [Geist] [25, с. 25]. Согласно полученным данным, треть опрошенных алтайцев (37 \%) отметили, что одной из трудностей для них в городе стала необходимость соблюдать правила безопасности, особенно в вечернее время. Трудно дается бывшим сельским жителям привыкание к особенностям урбанизированной среды, связанной с загрязнённым воздухом, водой и т.д. Достаточно медленно алтайцы включаются в культурно-досуговую жизнь города: основные виды досуга опрошенных связаны с прогулками (31 \%) и "ничегонеделанием" (32 \%).

С одной стороны, можно предположить, что смена места жительства для алтайцев, скорее, связана с положительными изменениями: больше трети (35 \%) опрошенных полностью удовлетворены своей жизнью, и ещё половина (54\%) скорее удовлетворена. Но с другой стороны, треть (34 \%) опрошенных алтайцев не видят особых изменений в своей жизни после переезда в город, полагая, что их жизнь осталась прежней. Вместе с тем отношение к жизни у алтайцев достаточно оптимистичное: среди них меньше всего пессимистично настроенных приезжих.

У тувиниев более выпуклыми являются мотивы переезда, связанные со стремлением к лучшей жизни из-за низкого уровня жизни в сельской местности, из-за безработицы. Согласно полученным результатам, тувинцы по сравнению с алтайцами в меньшей степени склонны мигрировать в город для получения образования (образовательные мотивы находятся на последнем месте). Однако тувинцы легко принимают новую роль горожанина (60 \%) (рис. 1), хотя и продолжают сохранять тесные связи с селом. У тувинцев по сравнению с другими этносами, участвующими в опросе, больше развиты нормы взаимопомощи: они чаще других обращаются за помощью, например, берут деньги взаймы. Возможно, более легкое включение в городскую среду объясняется большинством тувинцев в городской местности, поэтому адаптация у них проходит легче. При этом почти половина опрошенных допускает для 
Рис. 4. Степень удовлетворенности алтайцев, тувинцев и хакасов своей жизнью, в \% от ответивших

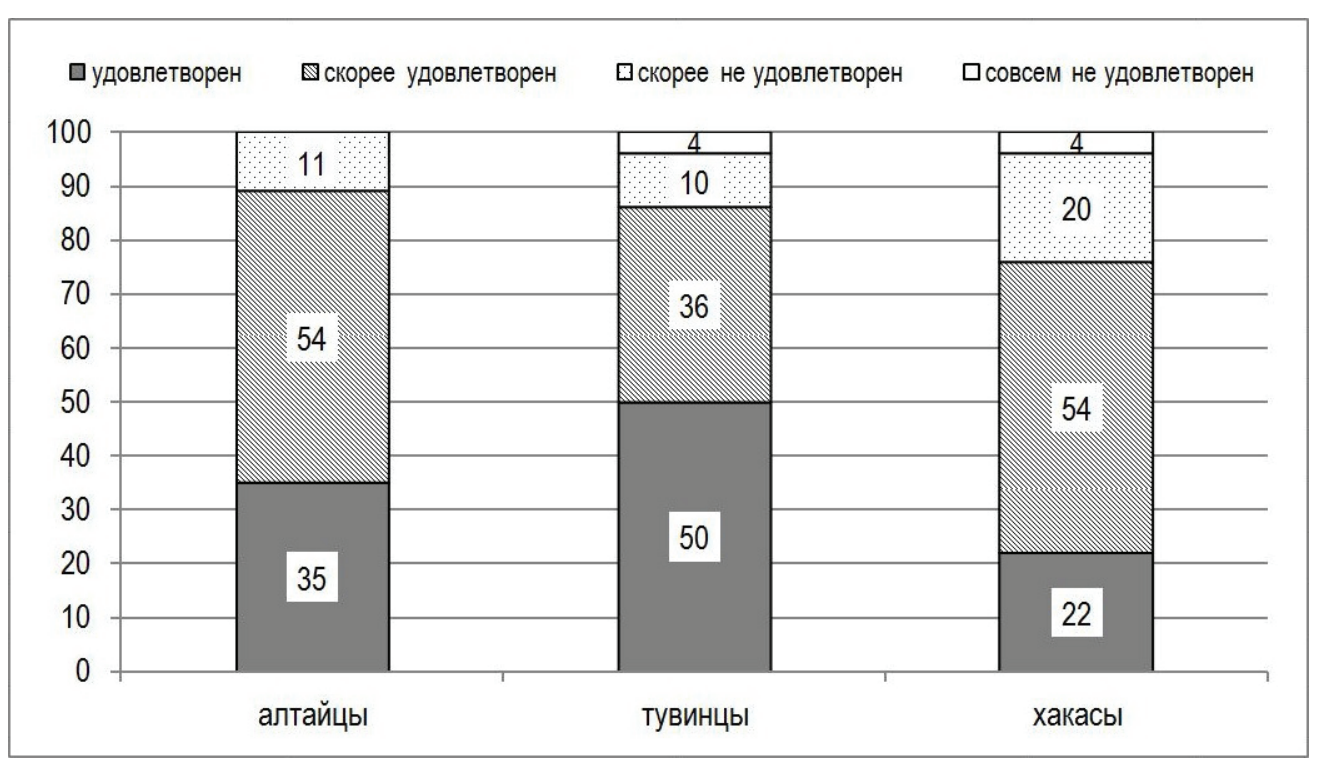

Источник: составлено автором

себя возможность смены места жительства, однако более выраженной среди них является внутрирегиональная миграция: две трети (65 \%) респондентов в случае предполагаемого отъезда планируют мигрировать внутри региона, причём $43 \%$ в другой город республики и ещё $22 \%$ допускают вероятность возвращения в родное село (рис. 3).

Поскольку основные мотивы миграции тувинцев связаны с экономическими фракторами, поэтому и основные трудности, с которыми сталкиваются бывшие сельчане, тоже носят экономический характер (отсутствие жилья, высокие цены). Хотя адаптация к новым экологическим условиям дается тоже нелегко: приезжие отмечают бесконечный шум на улицах, грязный воздух, общественный транспорт и т.д. В целом включение в городскую среду у тувинцев не связано с кардинальными изменениями своего образа жизни: большинство опрошенных предпочитает незатратные виды отдыха: прогулки (34 \%), занятия спортом (22 \%), "ничегонеделание" (22\%).

Адаптация к новым видам трудовой деятельности проходит достаточно легко, что объясняется тем, что в нынешних условиях границы между городом и селом не такие рельефные, и элементы некоторых "городских" профрессий распространены и в сельской местности (компьютер, Интернет). Вообще согласно исследованиям, менее привлекательными для тувинцев являются профессии, характеризующиеся жёстким режимом работы (промышленность), и более привлекательными - работы с относительно свободным графиком работы (научная, педагогическая деятельность, медицина) [7, с. 138].

В целом можно сказать, что для тувинцев переезд в город, скорее, рассматривается позитивно: большая часть опрошенных положительно оценивает изменения своей жизни после переезда в город и демонстрирует высокую удовлетворенность своей жизнью (рис. 4).

$\boldsymbol{X a \kappa a c b ~ п о ~ с р а в н е н и ю ~ с ~ а л т а и ̆ ц а м и ~ и ~ т у в и н ц а м и ~ м е н е е ~ в с е г о ~ н а ц е л е н ы ~}$ на возвратную миграцию: 73 \% ответили, что не планируют менять место жительства, а из тех, кто допускает такую возможность, больше половины (58 \%) ориентируется на переезд за пределы республики (рис. 3). Поэтому можно сказать, что для хакасов переезд из села рассматривается, скорее, как окончательный, поскольку в большей степени является вынужденным - связан с безработицей, низким уровнем жизни и в целом с отсутствием перспектив, хотя образовательные мотивы у хакасов тоже присутствуют. Может быть, поэ- 
Рис. 5. Соотношение алтайцев, тувинцев и хакасов, работающих в сферах занятости с разным характером труда, в \% от работающих респондентов

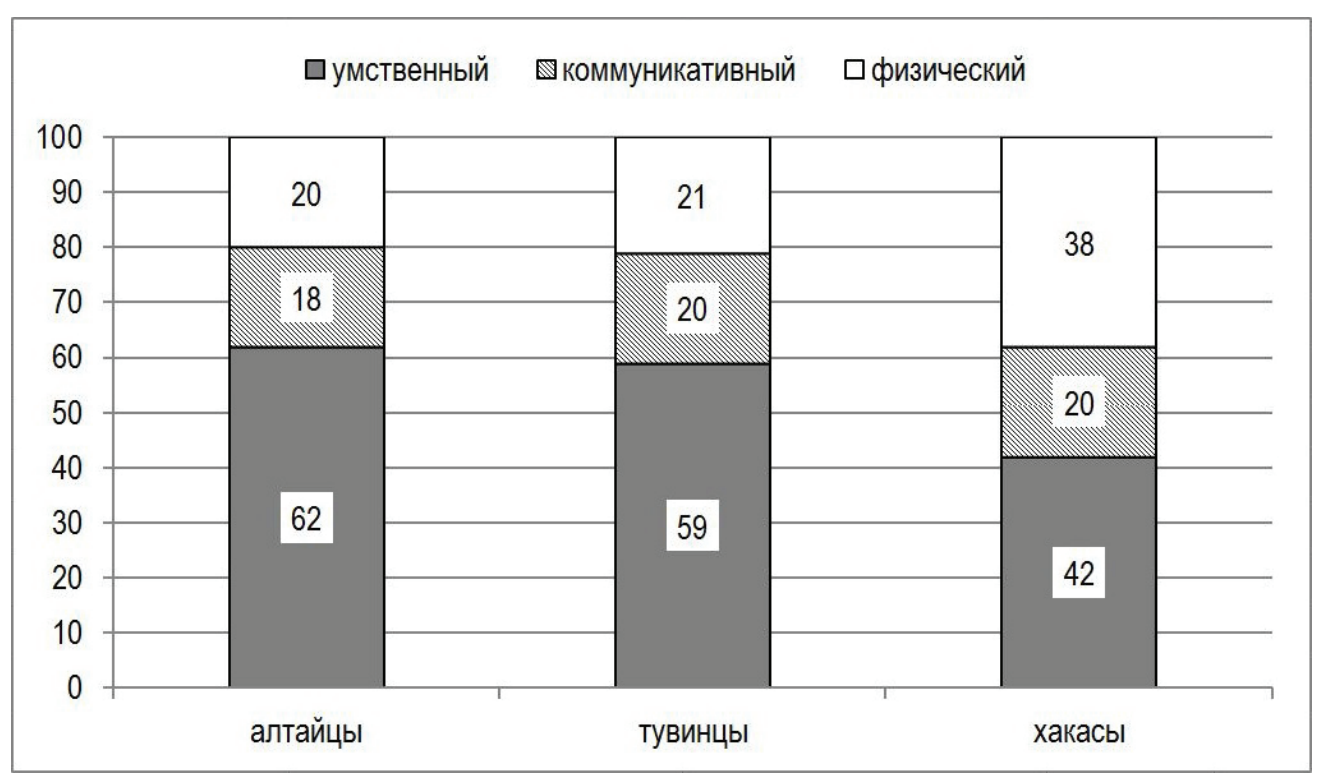

Источник: составлено автором

тому они легче разрывают связи с селом и принимают новую роль в качестве горожанина: почти половина (48 \%) ощущают себя городскими жителями и ещё 28 \% позиционируют себя двояко (рис. 1). Взаимодействие с акторами городской среды дается хакасам сравнительно легко: больше половины из них поддерживают дружеские отношения со своими соседями. Хакасы не испытывают в городе сложностей взаимодействия с русскими (как, например, алтайцы), поскольку в сельской местности Хакасии русские тоже составляют большинство, и в этом смысле переезд в город не связан с кардинальным изменением этнической и языковой среды.

По сравнению с алтайцами и тувинцами хакасы меньше испытывают трудности освоения городского образа жизни. С одной стороны, они тоже больше склонны к незатратному времяпровождению (прогулки 48 \%), но с другой стороны, осваивают и городские виды досуга (например, посещают кинотеатры). Однако по сравнению с представителями других этносов, участвовавшими в опросе, среди хакасов оказалось больше занятых в сфрерах фризического труда (рuс. 5).

Оказалось, что среди опрошенных хакасов 38 \% работают в сфрерах фризического труда и ещё 20 \% в сферах, связанных преимущественно с общением с людьми.

\section{Сохранение этнической идентичности}

Вовлечение коренных народов в урбанизационные процессы грозит размыванием или даже потерей этнической идентичности, особенно если в городской среде преобладает иноэтническое большинство. Оказалось, что наиболее сохранна этническая идентичность у тувинцев (50 \%), причём в общей структуре идентичностей она находится на втором месте после региональной ("житель своей республики"). У алтайцев этническая идентичность находится на третьем месте в общей структуре идентичностей (46 \%). Примечательно, что региональная идентичность у алтайцев находится на последнем месте в общей структуре идентичностей: только $6 \%$ респондентов позиционируют себя жителями своей республики, более выраженной у них является общероссийская идентичность ("житель России"). У хакасов этническая идентичность тоже находится на третьем месте, однако она менее выражена, чем у других 
Таблица 2. Владение родным языком среди алтайцев, тувинцев и хакасов

\begin{tabular}{|l|r|r|r|}
\hline & алтайцы & тувинцы & хакасы \\
\hline Численность титульного этноса, владеющего родным языком & 48583,0 & 241092,0 & 39735,0 \\
\hline Удельный вес титульного этноса, владеющего родным языком & 70,6 & 96,7 & 62,4 \\
\hline
\end{tabular}

Составлено по: [14, с. 210, 212, 213].

этносов: всего треть (36 \%) хакасов ощущают себя представителями своей национальности.

Вообще у хакасов более выраженным основанием этнической идентичности является культура и традиции (60\%), тогда как тувинцев и алтайцев в большей степени роднит язык (62\% и $66 \%$ соответственно). Возможно, это связано с тем, что хакасы по сравнению с тувинцами и алтайцами хуже знают свой родной язык (табл. 2).

Данные нашего исследования тоже показали, что только 39 \% опрошенных хакасов свободно владеют родным языком, среди алтайцев и тувинцев таковых $84 \%$ и $88 \%$ соответственно. Реже хакасы разговаривают на родном языке и в повседневной жизни (19\%) в отличие от алтайцев и тувинцев (45\% и $59 \%$ соответственно).

Безусловно, численное большинство титульного этноса на территории региона способствует сохранению родного языка, поэтому тувинцы в большей степени сохранили свой язык. Хакасы, находясь в условиях этнического меньшинства, хуже знают родной язык, поскольку в повседневной жизни чаще пользуются русским языком. Казалось бы, алтайцы тоже находятся в подобной ситуации, но в отличие от хакасов число владеющих алтайским языком среди них больше. Возможно, это связано со сложными взаимоотношениями алтайцев с русскими на территории республики, которые сдерживали процессы ассимиляции титульного этноса с русскоговорящим населением и тем самым позволили сохранить родной язык.

\section{Выводы}

Урбанизация алтайцев, тувинцев и хакасов протекала в разных исторических, географических, политических, социокультурных условиях, которые повлияли на характер и направленность процессов адаптации. В целом можно сделать вывод о том, что для каждого из этносов характерен свой тип урбанизации. Основные причины миграции алтайцев связаны с образовательными мотивами миграции, поскольку в республике всего одно городское поселение, а переезд в город чаще рассматривается как временный. Из-за численного меньшинства, а также по причине сложных исторически сложившихся отношений с русским населением на территории региона, алтайцы, скорее, сегрегируются, нежели интегрируются в городскую среду. Хотя такая стратегия сдерживает процесс ассимиляции с этническим большинством и тем самым способствует сохранению родного языка, но в целом препятствует включению этноса в урбанизационные процессы. Тувиниы сравнительно недавно начали интенсивно мигрировать в города, поэтому можно сказать, что городская среда в регионе только начинает фборлироваться, причём преимущественно титульным этносом. В представлении М. Ларуэла, такие города могут играть "деколонизирующую" роль в смысле постепенного стирания чисто европейского аспекта города и превращения его как в более местный и укорененный [32, p. 149]. Хaкасы на территории республики находятся в условиях абсолютного меньшинства (как в городской, так и в сельской местности), поэтому переезд в город в целом не связан с кардинальным изменением этноязыковой среды. В данном случае целесообразнее говорить не столько об адаптации, сколько об ассилиляции. Поэтому в отношении хакасского этноса более вероятен неблагоприятный прогноз, связанный с сокращением численности этноса и исчезновением родного языка.

Проводя параллели с типами адаптации, выделенными У. Томасом и Ф. Знанецким [37, p. 935], можно заключить, что для алтайцев, скорее ха- 
рактерен мещанский механизм адаптации, связанный с конформизмом и ориентацией на традиционные, устоявшиеся модели поведения, которые препятствуют активному вовлечению в урбанизационные процессы. Адаптация тувинцев имеет общие черты с богелныл типом, заключающем в себе и высокую степень адаптивности, и некоторую непоследовательность процесса адаптации. Несмотря на активную миграцию из села для улучшения своей жизни, тувинцы, по мнению исследователей, отличаются пассивной жизненной позицией, связанной с ожиданием помощи со стороны государства [3, с. 74]. Хакасы относительно легко и быстро адаптируются к условиям городской жизни, поэтому процесс их адаптации в некотором смысле можно отнести к креативнолу типу (хоть и частично). Этот тип адаптивного поведения отличается наиболее высокой степенью адаптивности.

Казалось бы, урбанизация происходит путем "бегства коренных народов" из традиционных сельских поселений в городские районы [35, p. 54], и, конечно, это грозит утратой этнической идентичности и "забыванием" языка. Но, учитывая сложное социально-экономическое положение в сельской местности (где проживает большая часть титульных этносов), возможно, переезд из села в город для них является более оптимальной стратегией "выживания". Другими словами, на первый план выступает стратегия не "куда", а "откуда" уехать [5, с. 11].

\section{Литература}

1. Алексеев А.И., Сарронов С.Г. Изменение сельского расселения в России в конце XX - начале XXI в. // Вестник Московского университета. 2015. Серия 5. Географрия. № 2. С. 66-76.

2. Анайбан 3.В. Трудовая занятость и социально-продессиональные ориентации молодежи современной Тувы // Новые исследования Тувы. 2018. № 2. С. 112-131. DOI: $10.25178 /$ nit.2018.2.6

3. Балакина Г.Ф., Кылгыдай Ай.К.Ч. Особенности адаптации этнических групп Тувы к рыночной экономике // Новые исследования Тувы. 2016. № 2. С. 73-89.

4. Белошапкина В.Н. Роль миграции в освоении хакасами нетрадиционных профессий // Торжество ленинской национальной политики. Абакан: Советская Хакасия. 1973. C. $143-154$.

5. Винокурова А.В., Ардальянова А.Ю., Шарихван Ж. Уехать "куда" или "откуда": условия жизни и миграционные стратегии жителей дальневосточного российско-китайского приграничья // Ойкумена. Регионоведческие исследования. 2020. № 4 (55). C. 7-15. DOI: $10.24866 / 1998-6785 / 2020-4 / 7-15$

6. Вебер М. Город. М.: Strelka Press, 2017. 252 c.

7. Дабиев Д.Ф. Профессиональные предпочтения населения Тувы в контексте экономической культуры // Новые исследования Тувы. 2018. № 2. C. 132-148. DOI: 10.25178/nit.2018.2.7

8. Диланян А. Стать горожанином: сельские мигранты в современном Ереване // Наблюдая за изменениями: стратегии адаптации на Южном Кавказе. Сборник статей. Тбилиси: Южно-Кавказское региональное бюро Фонда им. Генриха Белля, 2011. C. $26-44$.

9. Дискин И.С., Авраамова Е.М. Адаптация населения и элит (Институциональные предпосылки) // Общественные науки и современность. 1997. № 1. С. 24-33.

10. Дятлов В.И. Механизмы адаптации представителей мигрантских меньшинств в переселенческом обществе востока позднеимперской России // Известия Иркутского государственного университета. Серия: История. 2012. № 2-1. С. 262-269.

11. Екеев Н.В. Алтай: История и культура (Избранные труды) / БНУ РА "Научно-исследовательский институт алтаистики им. С.С. Суразакова". Горно-Алтайск: ООО "Горно-Алтайская типография", 2015. 472 с.

12. Зиммель Г. Большие города и духовная жизнь // Логос. 2002. Т. 3. № 34. С. $1-12$.

13. Итоги Всероссийской переписи населения 2010 года: В 11 т. / Федер. служба гос. статистики. М.: ИИЦ "Статистика России", 2012. Т. 1: Численность и размещение населения. $1071 \mathrm{c.}$

14. Итоги Всероссийской переписи населения 2010 года: В 11 т. / Федер. служба гос. статистики. М.: ИИЦ "Статистика России", 2012. Т. 4: Наџиональный состав и владение языками, гражданство. Кн. 1.847 с.

15. Итоги Всероссийской переписи населения 2010 года: В 11 т. / Федер. служба гос. статистики. М.: ИИЦ "Статистика России", 2013. Т. 10. Рождаемость. Кн. 2. 920 с. 
16. Казенин К.И. Адаптация сельских мигрантов в городах интенсивной урбанизации: case Махачкала. М.: Российская академия народного хозяйства и государственной служббы при Президенте Российской Федерации, 2016. 48 с.

17. Кан В.С. Этносоциальный профиль тувинцев // Новые исследования Тувы. 2016. № 2. C. 52-72.

18. Монгуш С.О.О. Межэтническое взаимодействие и формирование русского населения в Туве // Современная наука: актуальные проблемы теории и практики. Серия: Познание. 2020. № 6. С. 65-70. DOI 10.37882/2500-3682.2020.06.12

19. Мукомель В.И. Мигранты на российском рынке труда: занятость, мобильность, интенсивность и оплата труда // Статистика и экономика. 2017. № 6. С. 69-79. DOI: 10.21686/2500-3925-2017-6-69-79

20. Население Республики Хакасия за 2001-2011 годы. Статистический сборник // Росстат. Территориальный орган фредеральной службы государственной статистики по Республике Хакасия. Абакан, 2012. 31 с.

21. Остапенко Л.В. Социально-экономические аспекты адаптации русских и хакасов к условиям трансформирующегося общества (по материалам этносоциологического исследования в Хакасии). М.: Институт этнологии и антропологии РӒН. Центр по изучению межнациональных отношений, 2003. 26 с.

22. Свиридов Н.А. Адаптационные процессы в среде молодежи (Дальневосточная ситуация) // Социологические исследования. 2002. № 1. С. 90-95.

23. Тадина Н.А. О трех этапах модернизации родового общества алтайцев // Известия Иркутского государственного университета. Серия Геоархеология. Этнология. Антропология. 2019. T. 28. C. 88-97. DOI: 10.26516/2227-2380.2019.28.88

24. Тарбастаева И.С. Ценностно-экономические ориентации тувинцев в современной социокультурной динамике // Сибирский философрский журнал. 2017. Т. 15. № 4. C. 154-162. DOI: $10.25205 / 2541-7517-2017-15-4-154-162$

25. Теннис Ф. Общность и общество. Основные понятия чистой социологии. СПб.: Изд-во "Владимир Даль", 2002. 452 с.

26. Тюхтенева С.П. Скотоводство у алтайцев в начале XXI века // Полевые исследования. 2016. № 3. С. 65-81.

27. Чуднова В.И., Кожуховская Н.Ф. Население Саянского ТПК (формирование и расселение). Новосибирск: Изд-во "Наука", 1979. 120 с.

28. Шабанова М.А. Социальная адаптация в контексте свободы // Социологические исследования. 1995. № 9. С 81-88.

29. Dedeoglu S. Survival of the Excluded: Azerbaijani Immigrant Women's Survival Strategies and Industrial Work in Istanbul // Migration Letters. 2011. Vol. 8. No 1. Pp. $26-33$.

30. Erman T. Becoming "Urban" or Remaining "Rural": The Views of Turkish Ruralto-Urban Migrants on the "Integration" Question // International Journal of Middle East Studies. 1998. Vol. 30. No 4. Pp. 541-561.

31. Laruelle, M. Postcolonial polar cities? New indigenous and cosmopolitan urbanness in the Arctic // Acta Borealia. 2019. Vol. 36. Issue 2. Pp. 149-165. DOI: $10.1080 / 08003831.2019 .1681657$

32. Park R., Burgess E., McKenzie R. The City: Suggestions for the Investigation of Human Nature in the Urban Environment, Chicago: The University of Chicago Press, 1925. $240 \mathrm{p}$.

33. Redfield R. The Folk Society // American Journal of Sociology. 1947. Vol. 52. No 4. Pp. 293-308.

34. Rokib A., Islam R. Effect of Some Selected Sociodemographic Variables on Male Migrants on Bangladesh // Current Research Journal of Economic Theory. 2009. Vol. 1. No 1. Pp. $10-14$.

35. Rozanova, M. Indigenous Urbanization in Russia's Arctic The Case of Nenets Autonomous Region // Sibirica-interdisciplinary Journal Of Siberian Studies. 2019. Vol. 18. No. 3. P. 54-91. DOI: 10.3167/sib.2019.180304

36. Shi Li. Rural Migrant Workers in China: Scenario, Challenges and Public Policy, Geneva: International Labour Office, 2008. 34 p.

37. Thomas W.I., Znaniecki F. The Polish peasant in Europe and America. Monograph of an immigrant group. V. 5. Organization and disorganization in America, Boston: The Gorham Press. 1920. 345 p.

\section{Транслитерация по ГОСТ 7.79-2000 система Б}

1. Alekseev A.I., Safronov S.G. Izmenenie sel'skogo rasseleniya v Rossii v kontse XX - nachale XXI v. // Vestnik Moskovskogo universiteta. 2015. Seriya 5. Geografiya. № 2. S. 66-76.

2. Anajban Z.V. Trudovaya zanyatost' i sotsial'no-professional'nye orientatsii molodezhi sovremennoj Tuvy // Novye issledovaniya Tuvy. 2018. № 2. S. 112-131. DOI: 10.25178/nit.2018.2.6 
3. Balakina G.F., Kylgydaj Aj.K.CH. Osobennosti adaptatsii ehtnicheskikh grupp Tuvy k rynochnoj ehkonomike // Novye issledovaniya Tuvy. 2016. № 2. S. 73-89.

4. Beloshapkina V.N. Rol' migratsii v osvoenii khakasami netraditsionnykh professij // Torzhestvo leninskoj natsional'noj politiki. Abakan: Sovetskaya KHakasiya. 1973. S. $143-154$.

5. Vinokurova A.V., Ardal'yanova A.YU., SHarikhvan ZH. Uekhat' "kuda" ili "otkuda": usloviya zhizni i migratsionnye strategii zhitelej dal'nevostochnogo rossijsko-kitajskogo prigranich'ya // Ojkumena. Regionovedcheskie issledovaniya. 2020. № 4 (55). S. 7-15. DOI: $10.24866 / 1998-6785 / 2020-4 / 7-15$

6. Veber M. Gorod. M.: Strelka Press, 2017. 252 s.

7. Dabiev D.F. Professional'nye predpochteniya naseleniya Tuvy v kontekste ehkonomicheskoj kul'tury // Novye issledovaniya Tuvy. 2018. № 2. S. 132-148. DOI: 10.25178/ nit.2018.2.7

8. Dilanyan A. Stat' gorozhaninom: sel'skie migranty v sovremennom Erevane // Nablyudaya za izmeneniyami: strategii adaptatsii na YUzhnom Kavkaze. Sbornik statej. Tbilisi: YUzhno-Kavkazskoe regional'noe byuro Fonda im. Genrikha Bellya, 2011. S. 26-44.

9. Diskin I.S., Avraamova E.M. Adaptatsiya naseleniya i ehlit (Institutsional'nye predposylki) // Obshhestvennye nauki i sovremennost'. 1997. № 1. S. 24-33.

10. Dyatlov V.I. Mekhanizmy adaptatsii predstavitelej migrantskikh men'shinstv v pereselencheskom obshhestve vostoka pozdneimperskoj Rossii // Izvestiya Irkutskogo gosudarstvennogo universiteta. Seriya: Istoriya. 2012. № 2-1. S. 262-269.

11. Ekeev N.V. Altaj: Istoriya i kul'tura (Izbrannye trudy) / BNU RA "Nauchno-issledovatel'skij institut altaistiki im. S.S. Surazakova". Gorno-Altajsk: OOO "Gorno-Altajskaya tipografiya", 2015. $472 \mathrm{~s}$.

12. 'Zimmel' G. Bol'shie goroda i dukhovnaya zhizn' // Logos. 2002. T. 3. № 34. S. 1-12.

13. Itogi Vserossijskoj perepisi naseleniya 2010 goda: V 11 t. / Feder. sluzhba gos. statistiki. M.: IITS "Statistika Rossii", 2012. T. 1: CHislennost' i razmeshhenie naseleniya. $1071 \mathrm{~s}$

14. Itogi Vserossijskoj perepisi naseleniya 2010 goda: V 11 t. / Feder. sluzhba gos. statistiki. M.: IITS "Statistika Rossii", 2012. T. 4: Natsional'nyj sostav i vladenie yazykami, grazhdanstvo. Kn. $1.847 \mathrm{~s}$.

15. Itogi Vserossijskoj perepisi naseleniya 2010 goda: V 11 t. / Feder. sluzhba gos. statistiki. M.: IITS "Statistika Rossii", 2013. T. 10. Rozhdaemost'. Kn. 2. 920 s.

16. Kazenin K.I. Adaptatsiya sel'skikh migrantov v gorodakh intensivnoj urbanizatsii: case Makhachkala. M.: Rossijskaya akademiya narodnogo khozyajstva i gosudarstvennoj sluzhby pri Prezidente Rossijskoj Federatsii, 2016. 48 s.

17. Kan V.S. EHtnosotsial'nyj profil' tuvintsev // Novye issledovaniya Tuvy. 2016. № 2. S. $52-72$.

18. Mongush S.O.O. Mezhehtnicheskoe vzaimodejstvie i formirovanie russkogo naseleniya v Tuve // Sovremennaya nauka: aktual'nye problemy teorii i praktiki. Seriya: Poznanie. 2020. № 6. S. 65-70. DOI 10.37882/2500-3682.2020.06.12

19. Mukomel' V.I. Migranty na rossijskom rynke truda: zanyatost', mobil'nost', intensivnost' i oplata truda // Statistika i ehkonomika. 2017. № 6. S. 69-79. DOI: 10.21686/25003925-2017-6-69-79

20. Naselenie Respubliki KHakasiya za 2001-2011 gody. Statisticheskij sbornik // Rosstat. Territorial'nyj organ federal'noj sluzhby gosudarstvennoj statistiki po Respublike KHakasiya. Abakan, 2012. 31 s.

21. Ostapenko L.V. Sotsial'no-ehkonomicheskie aspekty adaptatsii russkikh i khakasov $\mathrm{k}$ usloviyam transformiruyushhegosya obshhestva (po materialam ehtnosotsiologicheskogo issledovaniya v KHakasii). M.: Institut ehtnologii i antropologii RAN. TSentr po izucheniyu mezhnatsional'nykh otnoshenij, 2003. $26 \mathrm{~s}$.

22. Sviridov N.A. Adaptatsionnye protsessy v srede molodezhi (Dal'nevostochnaya situatsiya) // Sotsiologicheskie issledovaniya. 2002. № 1. S. 90-95.

23. Tadina N.A. O trekh ehtapakh modernizatsii rodovogo obshhestva altajtsev // Izvestiya Irkutskogo gosudarstvennogo universiteta. Seriya Geoarkheologiya. EHtnologiya. Antropologiya. 2019. T. 28. S. 88-97. DOI: 10.26516/2227-2380.2019.28.88

24. Tarbastaeva I.S. TSennostno-ehkonomicheskie orientatsii tuvintsev v sovremennoj sotsiokul'turnoj dinamike // Sibirskij filosofskij zhurnal. 2017. T. 15. № 4. S. 154-162. DOI: $10.25205 / 2541-7517-2017-15-4-154-162$

25. Tennis F. Obshhnost' i obshhestvo. Osnovnye ponyatiya chistoj sotsiologii. SPb.: Izd-vo "Vladimir Dal'", 2002. $452 \mathrm{~s}$.

26. Tyukhteneva S.P. Skotovodstvo u altajtsev v nachale XXI veka // Polevye issledovaniya. 2016. № 3. S. 65-81.

27. CHudnova V.I., Kozhukhovskaya N.F. Naselenie Sayanskogo TPK (formirovanie i rasselenie). Novosibirsk: Izd-vo "Nauka", 1979. $120 \mathrm{s.}$

28. SHabanova M.A. Sotsial'naya adaptatsiya v kontekste svobody // Sotsiologicheskie issledovaniya. 1995. № 9. S 81-88. 
29. Dedeoglu S. Survival of the Excluded: Azerbaijani Immigrant Women's Survival Strategies and Industrial Work in Istanbul // Migration Letters. 2011. Vol. 8. No 1. Pp. $26-33$.

30. Erman T. Becoming "Urban" or Remaining "Rural": The Views of Turkish Rural-to-Urban Migrants on the "Integration" Question // International Journal of Middle East Studies. 1998. Vol. 30. No 4. Pp. 541-561.

31. Laruelle, M. Postcolonial polar cities? New indigenous and cosmopolitan urbanness in the Arctic // Acta Borealia. 2019. Vol. 36. Issue 2. Pp. 149-165. DOI: 10.1080/08003831.2019.1681657

32. Park R., Burgess E., McKenzie R. The City: Suggestions for the Investigation of Human Nature in the Urban Environment, Chicago: The University of Chicago Press, 1925. $240 \mathrm{p}$.

33. Redfield R. The Folk Society // American Journal of Sociology. 1947. Vol. 52. No 4. Pp. 293-308.

34. Rokib A., Islam R. Effect of Some Selected Sociodemographic Variables on Male Migrants on Bangladesh // Current Research Journal of Economic Theory. 2009. Vol. 1. No 1. Pp. $10-14$.

35. Rozanova, M. Indigenous Urbanization in Russia's Arctic The Case of Nenets Autonomous Region // Sibirica-interdisciplinary Journal Of Siberian Studies. 2019. Vol. 18. No. 3. P. 54-91. DOI: $10.3167 /$ sib.2019.180304

36. Shi Li. Rural Migrant Workers in China: Scenario, Challenges and Public Policy, Geneva: International Labour Office, 2008. 34 p.

37. Thomas W.I., Znaniecki F. The Polish peasant in Europe and America. Monograph of an immigrant group. V. 5. Organization and disorganization in America, Boston: The Gorham Press. 1920. 345 p.

\section{Лушникова О. Л. Алтайцы, тувинцы, хакасы: вовлечение в урбанизаци- онные процессы. \\ Фокус статьи направлен на анализ адаптационных процессов алтайцев,} тувинцев и хакасов при переселении из села в город. Статья построена на данных опроса титульных этносов республик Алтай, Тыва и Хакасия $(\mathrm{n}=960)$. Причины миграции алтайцев связаны с образовательными мотивами, и переезд в город чаще рассматривается как временный, поэтому алтайцы, скорее, сегрегируются, нежели интегрируются в городское сообщество. В Туве городская среда только начинает формироваться, причём преимущественно титульным этносом. Хакасы на территории региона находятся в условиях абсолютного меньшинства, поэтому в данном случае целесообразнее говорить об ассимиляции титульного этноса.

Ключевые слова: мигращия, адаптация, город, алтайщы, тувиниы, хакасы, этническая идентичность

\section{Lushnikova O. L. Altay people, Tuvans, Khakass people: involvement in urban processes. \\ The purpose of this article is analysis of adaptation processes of Altay people, Tuvans and Khakass people in case of moving from countryside to urban areas. The empirical base is the data of sociological survey of rural migrants by ethnic groups of the republics of Altay, Tuva and Khakassia $(n=960)$. The main migration reasons of Altay peoples are educational motivation, that's why moving to the urban territory is temporary. Altay people are segregated rather than adapted in urban area. The urban environment is just beginning to form, and mainly by titular ethnic group. Khakass people are tending to assimilation (not adaptation) because of an absolute minority on the territory of the republic.}

Key words: migration, adaptation, urban, Altay people, Tuvans, Khakass people, ethnic identity

Для цитирования: Лушникова О. Л. Алтайцы, тувинцы, хакасы: вовлечение в урбанизационные процессы // Ойкумена. Регионоведческие исследования. 2021. №3. С. 113-125. DOI: $10.24866 / 1998-6785 / 2021-3 / 113-125$

For citation: Lushnikova O. L. Altay people, Tuvans, Khakass people: involvement in urban processes // Ojkumena. Regional researches. 2021. № 3. P. 113-125. DOI: 10.24866/1998$6785 / 2021-3 / 113-125$ 